\title{
Infrageneric placement of the Southern Hemisphere taxa of Anemonastrum and Knowltonia earlier included in Anemone sensu lato (Ranunculaceae)
}

\author{
Sergei L. MOSYAKIN ${ }^{1}$, Peter J. de LANGE², Olena V. BULAKH ${ }^{1}$ \\ ${ }^{1}$ M.G. Kholodny Institute of Botany, National Academy of Sciences of Ukraine \\ 2 Tereschenkivska Str., Kyiv 01004, Ukraine \\ s_mosyakin@hotmail.com \\ ${ }^{2}$ Environment and Animal Sciences, Unitec Institute of Technology \\ Private Bag 92025, Victoria Street West, Auckland 1142, New Zealand \\ pdelange@unitec.ac.nz
}

Mosyakin S.L., de Lange P.J., Bulakh O.V. Infrageneric placement of the Southern Hemisphere taxa of Anemonastrum and Knowltonia earlier included in Anemone sensu lato (Ranunculaceae). Ukr. Bot. J., 2018, 75(6): 509-516.

Abstract. The genera Anemonastrum and Knowltonia earlier usually included in Anemone sensu lato (Ranunculaceae: Anemoneae) were recently proposed to be recognized in expanded circumscriptions, based on molecular phylogenetic findings and partly also morphological and biogeographical evidence. Both these genera contain some representatives that are noteworthy from morphological and biogeographical viewpoints, and the general ranges of these genera (combining the ranges of their included species) demonstrate remarkable continent-scale disjunctions. In particular, Knowltonia in its new circumscription (corresponding to Anemone sect. Pulsatilloides sensu Hoot et al., 2012) contains southern African and some American taxa (mostly South American ones, including Oreithales, Barneoudia, etc.), and K. crassifolia from Tasmania. Anemonastrum (corresponding to Anemone subg. Anemonidium sensu Hoot et al., excluding Hepatica) is mainly Eurasian, but it also includes several North American species, as well as A. antucense from southern South America and A. tenuicaule from New Zealand. Species of the newly outlined Anemonastrum and Knowltonia were placed in various infrageneric taxa of Anemone sensu lato. Following the re-circumscription of genera, it is now timely to nomenclaturally update and partly re-circumscribe the relevant infrageneric taxa earlier treated in Anemone sensu lato. Here we propose the following new combinations at the section and subsection ranks: Knowltonia sect. Mexicanae (Starod.) Mosyakin \& de Lange, comb. nov. (incl. K. mexicana); sect. Crassifoliae (Ulbr.) Mosyakin \& de Lange, comb. nov. (incl. K. crassifolia); sect. Rigidae (Ulbr.) Mosyakin \& de Lange, comb. nov. (incl. Knowltonia hootae = Anemone rigida, K. hepaticifolia, K. moorei); sect. Meridium (Starod.) Mosyakin \& de Lange, comb. nov. (incl. K. helleborifolia and K. peruviana), sect. Sellowiae (Hoot) Mosyakin \& de Lange, comb. nov. (incl. K. sellowii and K. assisbrasiliana); sect. Oreithales (Schltdl.) Mosyakin \& de Lange, comb. nov. (incl. K. integrifolia); sect. Barneoudia (Gay) Mosyakin \& de Lange, comb. nov. (incl. K. balliana, K. chilensis, K. major); sect. Pulsatilloides (DC.) Mosyakin \& de Lange, comb. nov.; [sect. Pulsatilloides] subsect. Alchemillifoliae (Ulbr.) Mosyakin \& de Lange, comb. nov. (incl. K. caffra and K. fanninii), and [sect. Pulsatilloides] subsect. Pinnatifoliae (Ulbr.) Mosyakin \& de Lange, comb. nov. (incl. K. tenuifolia). The new species-rank combination Knowltonia caffra (Eckl. \& Zeyh.) Christenh. \& Byng ex Mosyakin \& de Lange, comb. nov. is validated. The new subsectional name Anemonastrum sect. Anemonidium subsect. Makariri de Lange \& Mosyakin, subsect. nov. is proposed; this new subsection houses Anemonastrum antucense from South America and A. tenuicaule from New Zealand.

Keywords: Anemonastrum, Anemone, infrageneric classification, Knowltonia, nomenclature, Ranunculaceae, Southern Hemisphere, taxonomy

\section{Introduction}

In our earlier articles (Mosyakin, 2016, 2018a, b; Mosyakin, de Lange, 2018, and references therein) we discussed extensively the problem of a rational circumscription of genera in the group of Anemone L. sensu lato (Ranunculaceae: Anemoneae). In general, in these articles we favored a rather narrow circumscription

(C) S.L. MOSYAKIN, P.J. de LANGE, O.V. BULAKH, 2018

Укр. бот. журн., 2018, 75(6) of genus-rank entities, with recognition of the following genera: (1) Hepatica Mill., (2) Anemonastrum Holub (including Anemonidium (Spach) Holub, Arsenjevia Starod., Jurtsevia Á. Löve \& D. Löve, and Tamuria Starod.; corresponding mainly to Anemone subgen. Anemonidium sensu Hoot et al., 2012, but excluding Hepatica), (3) Knowltonia (corresponding to Anemone subg. Anemone sect. Pulsatilloides sensu Hoot et al., 2012), (4) Pulsatilla Mill., and (5) Anemone sensu stricto. 
These genera correspond to the main phylogenetic lineages (clades) outlined in recent molecular phylogenetic studies (e.g., Ehrendorfer, Samuel, 2000, 2001; Schuettpelz et al., 2002; Wang et al., 2009; Meyer et al., 2010; Pfosser et al., 2011; Hoot et al., 2012; Lehtonen et al., 2016; Jiang et al., 2017, and references therein). As reported by Lehtonen et al. (2016), Jiang et al. (2017), Liu et al. (2018b) and some other authors, the clade containing the genus Clematis L. (incl. Archiclematis (Tamura) Tamura and Naravelia Adans.: see Liu et al., 2018a, b) and its sister genus Anemoclema (Franch.) W.T.Wang (Wang et al., 2009; Jiang et al., 2017, 2018; Liu et al., 2018a, b) is phylogenetically rooted in Anemone sensu lato. Recent comparative analysis of complete chloroplast genomes of taxa of Anemoclema, Anemone, Pulsatilla, and Hepatica (Liu et al., 2018b) also indicated the placement of the Anemoclema + Clematis clade as sister to the Hepatica + Anemonastrum clade, well within the larger clade of Anemone sensu latissimo.

Consequently, if we follow the principles of phylogeny-based taxonomy not recognizing polyphyletic and paraphyletic taxa, we should either (1) unite Anemone sensu lato with Clematis sensu lato, with numerous new combinations needed and rather confusing nomenclatural and taxonomic outcomes, or (2) recognize several generic segregates from Anemone sensu lato, such as Anemonastrum, Hepatica, Knowltonia, Pulsatilla, Anemone sensu stricto (Mosyakin, 2016, 2018a, b; Mosyakin, de Lange, 2018; Christenhusz et al., 2018, and references therein), and probably also Eriocapitella Nakai (as recognized by Christenhusz and Byng in Christenhusz et al., 2018). The second option is preferred here and in our earlier publications (Mosyakin, 2016, 2018a, b; Mosyakin, de Lange, 2018), and is further justified and nomenclaturally implemented by Christenhusz and Byng (Christenhusz et al., 2018).

As suggested by Mosyakin (2016, 2018a) and explicitly proposed by Christenhusz and Byng (in Christenhusz et al., 2018), who validated most of the required species-level combinations and names in Knowltonia, this genus in its new much expanded circumscription includes both dry-fruited and fleshy-fruited southern African species, plus some American taxa (mainly from South America), and the geographically isolated Tasmanian K. crassifolia (Hook.) Christenh. \& Byng. The resulting wider genus, as compared to its traditional rather narrow circumscription (as recognized by Rasmussen, 1979; see also comments in Manning et al.,
2009; Mosyakin, 2018a), is morphologically rather diverse and, in our opinion, is in need of recognition of several morphologically and phylogenetically distinct infrageneric taxa. The corresponding infrageneric taxa have been considered, and some of them validated, by Hoot et al. (2012), mainly as subsections and series of Anemone (sensu lato) subg. Anemone sect. Pulsatilloides DC. Here these infrageneric entities are transferred to Knowltonia, in most cases with the change of their rank (the subsections recognized by Hoot et al. (2012) are mainly treated here as sections, etc.). Updated morphological descriptions and/or diagnoses for most of the infrageneric taxa considered below are provided in Hoot et al. (2012); additional taxonomic, nomenclatural, and morphological data on some taxa (species and/or species groups) are available from several other publications (e.g., Ulbrich, 1905, 1906; Starodubtsev, 1989, 1991; Tamura, 1991, 1993, 1995; Ziman et al., 2006, 2008, and references therein).

\section{Validation of new infrageneric combinations in Knowltonia}

Knowltonia Salisb. sect. Mexicanae (Starod.) Mosyakin \& de Lange, comb. nov.

Basionym: Anemonidium (Spach) Holub sect. Mexicana Starod., Bot. Zhurn. (Moscow \& Leningrad) 74(9): 1345. 1989. $\equiv$ Anemone L. [sect. Rivularidium Jancz.] ser. Mexicanae (Starod.) Ziman, Bulakh \& Kadota, J. Jap. Bot. 81(4): 196. 2006. 三 Anemone L. [subg. Anemone sect. Pulsatilloides DC.] subsect. Mexicanae (Starod.) Hoot, in Hoot \& al., Syst. Bot. 37(1): 148. 2012.

Type: Anemonidium mexicanum (Kunth.) Starod. (Starodubtsev, 1989), accepted here as Knowltonia mexicana (Kunth.) Christenh. \& Byng.

Species included: Knowltonia mexicana (Kunth.) Christenh. \& Byng (三Anemone mexicana Kunth).

Knowltonia Salisb. sect. Crassifoliae (Ulbr.) Mosyakin $\&$ de Lange, comb. nov.

Basionym: Anemone L. [sect. Rivularidium Jancz.] ser. Crassifoliae Ulbr., Bot. Jahrb. Syst. 37(2): 199. 1905 (as "Crassifolia"). झ Anemone L. [subg. Rivularidium (Jancz.) Juz.] sect. Crassifoliae (Ulbr.) Tamura, Acta Phytotax. Geobot. 42: 178. 1991, comb. inval. (as "sect. Crassifolia Ulbr.", without direct reference to the basionym; see Art. 41.5 of the ICN: Turland et al., 2018). $\equiv$ Anemone L. [subg. Anemone sect. Pulsatilloides DC.] subsect. Crassifoliae (Ulbr.) Hoot, in Hoot \& al., Syst. Bot. 37(1): 148. 2012. 
Type: Anemone crassifolia Hook. (the only species included in the protologue; see also Art. 10.8 of the ICN: Turland et al., 2018), now accepted as Knowltonia crassifolia (Hook.) Christenh. \& Byng.

Species included: Knowltonia crassifolia (Hook.) Christenh. \& Byng (三 Anemone crassifolia Hook.).

Knowltonia Salisb. sect. Rigidae (Ulbr.) Mosyakin \& de Lange, comb. nov.

Basionym: Anemone L. [sect. Rivularidium Jancz.] ser. Rigidae Ulbr., Bot. Jahrb. Syst. 37(2): 199. 1905 (as "Rigida"). $\equiv$ Anemone L. sect. Rigidae (Ulbr.) Tamura, Sci. Rep. Coll. Gen. Educ. Osaka Univ. 16: 28. 1967. $\equiv$ Anemone L. subgen. Rigida (Ulbr.) Tamura, Acta Phytotax. Geobot. 42(2): 178. 1991. $\equiv$ Anemonidium (Spach) Starod. [subg. Meridium Starod. sect. Meridium Starod.] subsect. Rigida (Ulbr.) Starod., Veterenitsy: sist. evol. [Ветреницы: систематика и эволюция]: 118. 1991. $\equiv$ Anemone L. [subg. Anemone sect. Pulsatilloides DC.] subsect. Rigidae (Ulbr.) Hoot, in Hoot \& al., Syst. Bot. 37(1): 149. 2012.

Type: Anemone rigida Gay (Art. 10.8 of the ICN: Turland et al., 2018), accepted here as Knowltonia hootae Christenh. \& Byng.

Species included: Knowltonia hepaticifolia (Hook. f.) Christenh. \& Byng (三Anemone hepaticifolia Hook. f.), $K$. hootae Christenh. \& Byng (三 Anemone rigida Gay, non Knowltonia rigida Salisb., nom. illeg.), K. moorei (Espinosa) Christenh. \& Byng (三 Anemone moorei Espinosa).

Knowltonia Salisb. sect. Meridium (Starod.) Mosyakin \& de Lange, comb. nov.

Basionym: Anemonidium (Spach) Holub sect. Meridium Starod., Bot. Zhurn. (Moscow \& Leningrad) 74(9): 1345. 1989.

= Anemonidium (Spach) Holub [sect. Meridium Starod.] subsect. Helleborifolia Starod., Bot. Zhurn. (Moscow \& Leningrad) 74(9): 1345. 1989. 三Anemone L. [subg. Rivularidium (Jacz.) Juz. sect. Rivularidium Jacz.] ser. Helleborifoliae Tamura, Acta Phytotax. Geobot. 42(2): 178. 1991 (published as "ser. nov.", with a brief Latin diagnosis). $\equiv$ Anemone L. [subg. Anemone sect. Pulsatilloides DC.] subsect. Helleborifoliae (Starod.) Hoot, in Hoot \& al., Syst. Bot. 37(1): 148. 2012.

Type: Anemonidium helleborifolium (DC.) Starod. (Starodubtsev, 1989), accepted here as Knowltonia helleborifolia (DC.) Christenh. \& Byng.

Species included: Knowltonia helleborifolia (DC.) Christenh. \& Byng (三 Anemone helleborifolia DC.), K. peruviana (Britton) Christenh. \& Byng (三 A. peruviana Britton).

Укр. бот. журн., 2018, 75(6)
Note: The infrageneric epithet Meridium has priority over Helleborifolia (Helleborifoliae if placed in Knowltonia or Anemone) if this infrageneric entity is recognized as a section (Art. 11.2 of the ICN: Turland et al., 2018).

Knowltonia Salisb. sect. Sellowiae (Hoot) Mosyakin \& de Lange, comb. nov.

Basionym: Anemone L. [subg. Anemone sect. Pulsatilloides DC.] subsect. Sellowiae Hoot, in Hoot \& al., Syst. Bot. 37(1): 148. 2012 (as "Sellowii").

Type: Anemone sellowii Pritz. (Hoot et al., 2018), accepted here as Knowltonia sellowii (Pritz.) Christenh. \& Byng.

Species included: Knowltonia sellowii (Pritz.) Christenh. \& Byng (三 Anemone sellowii Pritz.), K. assisbrasiliana (Kuhlm. \& Porto) Christenh. \& Byng ( $\equiv$ A. assisbrasiliana Kuhlm. \& Porto).

Knowltonia Salisb. sect. Oreithales (Schltdl.) Mosyakin \& de Lange, comb. nov.

Basionym: Oreithales Schltdl., Linnaea 27: 559. 1856. $\equiv$ Anemone L. [subg. Anemone sect. Pulsatilloides DC.] subsect. Oreithales (Schltdl.) Hoot, in Hoot \& al., Syst. Bot. 37(1): 149. 2012. इ Capethia Britton, Ann. New York Acad. Sci. 6: 235. 1891, nom. illeg.

Type: Oreithales integrifolia (DC.) Schltdl. (the only species included in the genus Oreithales in the protologue), accepted here as Knowltonia integrifolia (DC.) Christenh. \& Byng.

Species included: Knowltonia integrifolia (DC.) Christenh. \& Byng. ( $\equiv$ Hepatica integrifolia DC. $\equiv$ Anemone integrifolia (DC.) Spreng. $\equiv$ Oreithales integrifolia (DC.) Schltdl. $\equiv$ Capethia integrifolia (DC.) Britton).

Knowltonia Salisb. sect. Barneoudia (Gay) Mosyakin $\&$ de Lange, comb. nov.

Basionym: Barneoudia Gay, Fl. Chil. 1: 29, t. 1. 1845. $\equiv$ Anemone L. sect. Barneoudia (Gay) Prantl, in Engler \& Prantl, Nat. Pflanzenfam. 3(2): 62. 1891. 三 Anemone L. [subg. Anemone sect. Pulsatilloides DC.] subsect. Barneoudia (Gay) Hoot, in Hoot \& al., Syst. Bot. 37(1): 149. 2012.

Type: Barneoudia chilensis Gay (the only species included in the genus Barneoudia in the protologue), accepted here as Knowltonia chilensis (Gay) Christenh. \& Byng.

Species included: Knowltonia balliana (Britton) Christenh. \& Byng (三 Barneoudia balliana Britton $\equiv$ Anemone balliana (Britton) Hoot), K. chilensis (Gay) 
Christenh. \& Byng ( $\equiv$ Barneoudia chilensis Gay $\equiv$ Anemone chilensis (Gay) Kurtz), K. major (Phil.) Christenh. \& Byng (三 Barneoudia major Phil. $\equiv$ Anemone major (Phil.) F. Meigen).

Knowltonia Salisb. sect. Knowltonia

$\equiv$ Anemone L. sect. Knowltonia (Salisb.) Prantl, in Engler \& Prantl, Nat. Pflanzenfam. 3(2): 62. 1891. 三 Anemone L. ser. Knowltonia (Salisb.) J.C. Manning \& Goldblatt, Bothalia 39(2): 218. 2009.

Type (typus generi): Knowltonia rigida Salisb. (the only species included in Knowltonia by Salisbury, 1796), nom. illeg. (Adonis capensis L. cited in synonymy; Art. 52.1 and 52.2 of the ICN: Turland et al., 2018), now accepted as Knowltonia capensis (L.) Huth.

Species included: Knowltonia anemonoides H. Rasmussen ( $\equiv$ Anemone anemonoides (H. Rasmussen) J.C. Manning \& Goldblatt), K. bracteaea Harv. ex J. Zahlbr. ( $\equiv$ A. bracteata (Harv. ex J. Zahlbr.) J.C. Manning \& Goldblatt), K. brevistylis Szyszyl. (三A. brevistylis (Szyszyl.) J.C. Manning \& Goldblatt), K. cordata H. Rasmussen ( $\equiv A$. cordata (H. Rasmussen) J.C. Manning \& Goldblatt), K. filia (L. f.) T. Dur. \& Schinz (三A. filia (L. f.) J.C. Manning \& Goldblatt), K. capensis (L.) Huth ( $\equiv$ A. knowltonia Burtt Davy), K. vesicatoria (L. f.) Sims ( $\equiv$ A. vesicatoria (L. f.) Prantl), K. transvaalensis Szyszyl. ( $\equiv$ A. transvaalensis (Szyszyl.) Burtt Davy). See further taxonomic and morphological information in Rasmussen (1979) and Manning et al. (2009; taxa treated as species of Anemone sensu lato). Infraspecific taxa recognized by Rasmussen (1979) and Manning et al. (2009) are not considered here.

Knowltonia Salisb. sect. Pulsatilloides (DC.) Mosyakin \& de Lange, comb. nov.

Basionym: Anemone sect. Pulsatilloides DC., Syst. Nat. 1: 195. 1817. $\equiv$ Anemone L. subgen. Pulsatilloides (DC.) Juz., Flora URSS [Флора СССР] 7: 256. 1937, pro parte. $\equiv$ Pulsatilloides (DC.) Starod., Veterenitsy: sist. evol. [Ветреницы: систематика и эволюция]: 124. 1991, pro min. parte.

Type: Anemone capensis (L.) Lam. (lectotype, designated by Starodubtsev, 1991: 124) ( $\equiv$ Knowltonia pulsatilloides Christenh. \& Byng, non K. capensis (L.) Huth).

Note: Mosyakin (2018b: 6) already commented that the concept of the genus Pulsatilloides as outlined by Starodubtsev (1991), who included in that genus the members of Anemonastrum sect. Anemonastrum subsect. Himalayicae (Ulbr.) Mosyakin together with Pulsatilloides capensis (L.) Starod. (now recognized as Knowltonia tenuifolia (L. f.) Mosyakin, incl. K. pulsatilloides), P. glaucifolia (Franch.) Starod. (now properly accepted as Anemoclema glaucifolium (Franch.) W.T. Wang), and P. begoniifolia (H. Lév. \& Vaniot) Starod. (which is Anemone begoniifolia H. Lév. \& Vaniot, a member of Anemone sensu stricto), is "very unnatural phylogenetically and has not been confirmed by molecular, morphological, and karyological evidence". Anemone sect. Pulsatilloides as understood and circumscribed by Hoot et al. (2012) appears to be phylogenetically natural, but it was applied in a very wide sense to all taxa placed here and in Christenhusz et al. (2018) in the genus Knowltonia. Here the name Knowltonia sect. Pulsatilloides is restricted only to dryfruited southern African taxa, which we place in two subsections (see below).

Knowltonia Salisb. sect. Pulsatilloides subsect. Pinnatifoliae (Ulbr.) Mosyakin \& de Lange, comb. nov.

Basionym: Anemone [sect. Pulsatilloides DC.] ser. Pinnatifoliae Ulbr., Bot. Jahrb. Syst. 37(2): 200 (diagn.), 239. 1905.

Type: Anemone capensis (L.) Lam. (the only species included in the series in the protologue, cited with the authorship "(L.) DC.") (三 Knowltonia pulsatilloides Christenh. \& Byng, non K. capensis (L.) Huth).

Species included: Knowltonia tenuifolia (L. f.) Mosyakin (incl. K. pulsatilloides Christenh. \& Byng; see nomenclatural comments and synonymy in Mosyakin, 2018).

Note: If the second species (corresponding to Atragene capensis L. $\equiv$ Anemone capensis (L.) Lam. sensu stricto) is recognized in this subsection, its correct species-rank name in Knowltonia will be K. pulsatilloides Christenh. \& Byng (see, however, taxonomic and nomenclatural comments in Manning and Goldblatt, 2013, and Mosyakin, 2018a).

Knowltonia Salisb. sect. Pulsatilloides subsect. Alchemillifoliae (Ulbr.) Mosyakin \& de Lange, comb. nov.

Basionym: Anemone L. [sect. Pulsatilloides DC.] ser. Alchemillifoliae Ulbr., Bot. Jahrb. Syst. 37(2): 201. 1905 (as "Alchimillifoliae"). $\equiv$ Anemone L. sect. Alchemillifoliae (Ulbr.) Tamura, Acta Phytotax. Geobot. 42(2): 179. 1991 (as "Archimillifolia", sphalm.). 三 Anemone L. [subg. Anemone sect. Pulsatilloides DC.] subsect. Alchemillifoliae (Ulbr.) Hoot, in Hoot et al., Syst. Bot. 37(1): 149. 2012, pro parte (excl. Anemone tenuifolia).

Type: Anemone alchemillifolia E. Mey. ex Pritz. (Art. 10.8 of the ICN: Turland et al., 2018), a homotypic

Ukr. Bot. J., 2018, 75(6) 
synonym of Knowltonia caffra (Eckl. \& Zeyh.) Christenh. \& Byng ex Mosyakin \& de Lange, see below.

Species included: Knowltonia caffra (三Anemone caffra (Eckl. \& Zeyh.) Harv.), K. fanninii (Harv. \& Hook. f.) Christenh. \& Byng (三 A. fanninii Harv. \& Hook. f.); for further taxonomic and morphological information see Manning and Goldblatt (2013; taxa treated in Anemone sensu lato).

Note 1: Hoot et al. (2012: 149-150) reported the type of Anemone ser. Alchemillifoliae Ulbr. as "LECTOTYPE: designated by Tamura (1995): Anemone caffra Harv. Gen. S. Afr. P1. 9. 1838" and commented that "The source of the name "alchemillifolia" appears to be A. alchemillifolia E. Mey. ex Pritz. (Linnaea 15: 758 [erroneous page citation-S.M. \& P.dL.] 1842), synonymous with Pulsatilla (Anemone) caffra Eckl. \& Zeyh. (Enum. Pl. Afric. Austral. [Ecklon \& Zeyher] 1: 1. 1934-35)". However, according to Art. 10.8 of the ICN (Turland et al., 2018), "When the epithet in the name of a subdivision of a genus is identical with or derived from the epithet in one of the originally included species names, the type of the higher-ranking name is the same as that of the species name, unless the original author of the higher-ranking name designated another type". Ulbrich (1905) rather confusingly listed two accepted species of this series as "A. caffra (Eckl. et Zeyh.) Harvey" and "A. Fanninii Harvey" on page 201 (where the name "alchemillifolia E. Mey. in Pritzel, Revisio Gen. Anem. 1841" was also mentioned in a footnote), but on pages 188 and 240 of the same publication accepted $A$. alchemillifolia (including "var. caffra (Eckl. et Zeyh.) Huth" on page 240) and A. fanninii. Consequently, the name Anemone alchemillifolia E. Mey. ex Pritz. (an illegitimate and superfluous name because Pritzel (1842: 614) cited Pulsatilla caffra Eckl. \& Zeyh. in synonymy) is the type of the series and the lectotypification by Tamura (1995) was unnecessary.

Note 2: The name Anemone caffra was sometimes cited with the authorship of only Harvey (1838). However, this name is a nomenclatural combination based on Pulsatilla caffra Eckl. \& Zeyh. (Ecklon, Zeyher, 1834: 1). Christenhusz and Byng (in Christenhusz et al., 2018: 75) cited the name "Anemone caffra Harv. Gen. S. Afr. P.: 9. 1838" as the basionym of their new nomenclatural combination Knowltonia caffra. Since they failed to cite the correct basionym and the actual place of its valid publication, their new combination is invalid (Art. 41.5 of the ICN: Turland et al., 2018). This combination is validated below with the proper reference to its basionym. It should be also noted that the combination Anemone caffra was validated by Harvey in 1838 by his reference to "Pulsatilla caffra. Eck. and Zeyh.", not in 1859 as indicated by Manning and Goldblatt (2013: 6).

Knowltonia caffra (Eckl. \& Zeyh.) Christenh. \& Byng ex Mosyakin \& de Lange, comb. nov.

Basionym: Pulsatilla caffra Eckl. \& Zeyh., Enum. Pl. Afric. Austral. 1: 1. 1834 [Dec 1834 - Mar 1835]. $\equiv$ Anemone caffra (Eckl. \& Zeyh.) Harv., Gen. S. Afr. Pl.: 9. 1838. $\equiv$ Anemone alchemillifolia E. Mey. ex Pritz., Linnaea 15(6): 614. 1842 (as "alchemillaefolia"), nom. illeg. superfl. (Pulsatilla caffra cited in synonymy; Art. 52.1 and 52.2 of the ICN: Turland et al., 2018). $\equiv$ A. alchemillifolia E. Mey. ex Pritz. var. caffra (Eckl. \& Zeyh.) Huth, Bull. Herb. Boissier 4: 423. 1896. $\equiv$ Knowltonia caffra "(Harv.)" Christenh. \& Byng, Global Fl. 4: 75. 2018, nom. inval. (Art. 41.5 of the ICN: Turland et al., 2018).

\section{Validation of a new subsection in Anemonastrum}

Anemonastrum Holub sect. Anemonidium (Spach) Mosyakin subsect. Makariri de Lange \& Mosyakin, subsect. nov.

Type: Anemonastrum tenuicaule (Cheeseman) de Lange \& Mosyakin ( $\equiv$ Ranunculus tenuicaulis Cheeseman $\equiv$ Anemone tenuicaulis (Cheeseman) Parkin $\&$ Sledge $\equiv$ Anemonidium tenuicaule (Cheeseman) Christenh. \& Byng).

Species included: Anemonastrum antucense (Poepp.) Mosyakin \& de Lange (southern South America: Chile) and $A$. tenuicaule (Cheeseman) de Lange \& Mosyakin (New Zealand).

Description: Perennial rhizomatous herbaceous plants. Basal leaf blades $3-8(-10) \mathrm{cm}$ long, sparsely pubescent. Inflorescences 2-3-flowered or flowers solitary. Tepals (4-)5-15 $\mathrm{mm}$ long, without anastomosing veins, subglabrous, white to pinkishwhite (A. antucense) or pink to red or reddish-brown (A. tenuicaule). Carpels and achenes compressed, glabrous or subglabrous, shortly stalked (A. antucense), sessile or subsessile (A. tenuicaule), with hooked or spirally coiled styles.

Etymology: The name of the subsection is from the Te Reo Maori (Maori language) word for "cold" (also "winter") because the New Zealand species, the nomenclatural type of this subsection, is confined to cold and shady habitats, and it flowers in winter (astronomical summer in the Southern Hemisphere). 
Note: Two species of this subsection were included by various authors in several infrageneric taxa of Anemone sensu lato. For example, Ulbrich (1905) placed Anemonastrum antucense (as Anemone antucensis) in Anemone sect. Rivularidium Jancz. ser. Rivulares Ulbr. Ziman et al. (2006, 2008) included Anemone antucensis and A. tenuicaulis in Anemone sect. Rivularidium Jancz. ser. Jamesoniae Ziman, Bulakh \& Kadota (as "Jamesonii"), together with A. jamesonii Hook. f., A. sellowii, A. assibrasiliana, and A. moorei. Hoot et al. (2012) placed our two species in Anemone subgen. Anemonidium (Spach) Juz. sect. Anemonidium Spach together with $A$. canadensis L., A. dichotoma L., and A. richardsonii Hook. f., which are now recognized as Anemonastrum canadense (L.) Mosyakin, A. dichotomum (L.) Mosyakin, and A. richardsonii (Hook. f.) Mosyakin (see Mosyakin, 2016).

Trans-Pacific biogeographical links and phylogenetic relationships of $A$. antucense and $A$. tenuicaule were discussed by Ehrendorfer and Samuel (2000, 2001), Schuettpelz et al. (2002), Ziman et al. (2006, 2008), Meyer et al. (2010), Hoot et al. (2012), and some other authors. Information on taxonomy, nomenclature, morphology, and biogeography of $A$. tenuicaule and $A$. antucense was summarized in our earlier article (Mosyakin, de Lange, 2018).

\section{Acknowledgments}

We are grateful to Svetlana M. Ziman (M.G. Kholodny Institute of Botany of the National Academy of Sciences of Ukraine, Kyiv, Ukraine) for her advice, critical comments, and collaboration on our earlier articles on Anemone sensu lato. The useful comments of reviewers are also greatly appreciated.

\section{REFERENCES}

Christenhusz M.J.M., Fay M.F., Byng J.W. (eds.). The Global Flora. Vol. 4: Special Edition, GLOVAP Nomenclature Part 1. Bradford, United Kingdom: Plant Gateway Ltd., 2018, 155 pp.

Ecklon C.F., Zeyher C. Enumeratio plantarum Africae australis extratropicae quae collectae, determinatae et expositae a Christiano Frederico Ecklon \& Carolo Zeyher. Hamburgi [Hamburg]: Sumtibus auctorum; Prostat apud Perthes \& Besser, 1834 (1834-1835), vol. 1, 144 pp.

Ehrendorfer F., Samuel R. Comments on S.B. Hoot's interpretation of Southern Hemisphere relationships in Anemone (Ranunculaceae) based on molecular data [Am. J. Bot. 2000; 87(6, Suppl.), 154-155]. Taxon, 2000, 49: 781-784.

Ehrendorfer F., Samuel R. Contributions to a molecular phylogeny and systematics of Anemone and related genera
(Ranunculaceae - Anemoninae). Acta Phytotaxonomica Sinica, 2001, 39: 293-307.

Harvey W.H. The genera of South African plants: arranged according to the natural system. Cape Town: A.S. Robertson, 1838, lxvi + 429 pp.

Hoot S.B., Meyer K.M., Manning J.C. Phylogeny and reclassification of Anemone (Ranunculaceae), with an emphasis on Austral species. Systematic Botany, 2012, 37: 139-152. https://doi.org/10.1600/036364412X616729

Jiang N., Zhou Z., Yang J.-B., Zhang S.-D., Guan K.-Y., Tan Y.-H., Yu W.-B. Phylogenetic reassessment of tribe Anemoneae (Ranunculaceae): Non-monophyly of Anemone s. 1. revealed by plastid datasets. PLoS ONE, 2017, 12(3): e0174792 (17 pp.). https://doi.org/10.1371/ journal.pone. 0174792

Jiang N., Zhou Z., Yang J.-B., Yu W.-B. Complete chloroplast genome of Anemoclema glaucifolium (Ranunculaceae), a vulnerable and threatened species endemic to the Hengduan Mountains. Conservation Genetic Resources, 2018, 10: 601-604. https://doi.org/10.1007/ s12686-017-0874-2

Lehtonen S., Christenhusz M.J.M., Falck D. Sensitive phylogenetics of Clematis and its position in Ranunculaceae. Botanical Journal of the Linnean Society, 2016, 182: 825867. https://doi.org/10.1111/boj.12477

Liu H.J., Ding C.H., He J., Cheng J., Pei L.Y., Xie L. Complete chloroplast genomes of Archiclematis, Naravelia and Clematis (Ranunculaceae), and their phylogenetic implications. Phytotaxa, 2018a, 343: 214226. http://dx.doi.org/10.11646/phytotaxa.343.3.2

Liu H.J., He J., Ding C.H, Lyu R., Pei L.Y., Cheng J., Xie L. Comparative analysis of complete chloroplast genomes of Anemoclema, Anemone, Pulsatilla, and Hepatica revealing structural variations among genera in tribe Anemoneae (Ranunculaceae). Frontiers in Plant Science, 2018b, 9: 1097 (16 pp.). https://doi.org/10.3389/fpls.2018.01097

Manning J.C., Goldblatt P. A taxonomic review of the dryfruited species of Anemone (Ranunculaceae) in southern Africa. Bothalia, 2013, 43(1): 1-13. https://doi. org/10.4102/abc.v43i1.81

Manning J.C., Goldblatt P., Hoot S.B. The genus Knowltonia (Ranunculaceae) subsumed within Anemone. Bothalia, 2009, 39: 217-219. https://doi.org/10.4102/ abc.v39i2.246

Meyer K.M., Hoot S.B., Arroyo M.T.K. Phylogenetic affinities of South American Anemone (Ranunculaceae), including the endemic segregate genera, Barneoudia and Oreithales. International Journal of Plant Sciences, 2010, 171(3): 323-331. https://doi.org/10.1086/650153

Mosyakin S.L. Nomenclatural notes on North American taxa of Anemonastrum and Pulsatilla (Ranunculaceae), with comments on the circumscription of Anemone and related genera. Phytoneuron, 2016, 2016-79: 1-12. Available at: http://www.phytoneuron. net/2016Phytoneuron/79PhytoN-Anemonastrum.pdf

Mosyakin S.L. The correct name in Knowltonia for an iconic southern African species earlier known as Anemone tenuifolia and A. capensis (Ranunculaceae). Ukrainian Botanical Journal [Український ботанічний журнал], 
2018a, 75(3): 230-237. https://doi.org/10.15407/ ukrbotj75.03.230

Mosyakin S.L. Further new combinations in Anemonastrum (Ranunculaceae) for Asian and North American taxa. Phytoneuron, 2018b, 2018-55: 1-11. Available at: http://www.phytoneuron.net/2018Phytoneuron/55PhytoN-Anemonastrum.pdf

Mosyakin S.L., de Lange P.J. Anemonastrum tenuicaule and A. antucense (Ranunculaceae), new combinations for a New Zealand endemic species and its South American relative. PhytoKeys, 2018, 99: 107-124. https://doi. org/10.3897/phytokeys.99.26489

Pfosser M., Sun B.-Y., Stuessy T.F., Jang Ch.-G., Guo Y.-P., Taejin K., Hwan K.C., Kato H., Sugawara T. Phylogeny of Hepatica (Ranunculaceae) and origin of Hepatica maxima Nakai endemic to Ullung Island, Korea. Stapfia, 2011, 95: 16-27. Available at: https://www.zobodat.at/ pdf/STAPFIA_0095_0016-0027.pdf

Pritzel G.A. Anemonarum revisio. Linnaea, 1842 ("1841"), 15(6): 561-698.

Rasmussen H.N. The genus Knowltonia (Ranunculaceae). Opera Botanica, 1979, 53: 1-45. Available at: https://curis.ku.dk/ws/files/126327732/The_genus_ Knowltonia.pdf

Salisbury R.A. Prodromus stirpium in horto ad Chapel Allerton vigentium. Londini [London], 1796, viii $+422 \mathrm{pp}$. https://doi.org/10.5962/bhl.title.427

Schuettpelz E., Hoot S.B., Samuel R., Ehrendorfer F. Multiple origins of Southern Hemisphere Anemone (Ranunculaceae) based on plastid and nuclear sequence data. Plant Systematics and Evolution, 2002, 231: 143-151. https://doi.org/10.1007/s006060200016

Starodubtsev V.N. New taxa of the subtribe Anemoninae (Ranunculaceae). Botanicheskii Zhurnal, 1989, 74(9): 1344-1346. [Стародубцев В.Н. Новые таксоны подтрибы Anemoninae (Ranunculaceae). Ботанический журнал, 1989, 74(9): 1344-1346].

Starodubtsev V.N. Anemones: systematics and evolution. Leningrad: Nauka, 1991, 198 pp. [Стародубцев В.Н. Ветреницы: систематика и эволюция. Л.: Наука, 1991, 198 c.].

Tamura M. A new classification of the family Ranunculaceae 2. Acta Phytotaxonomica et Geobotanica, 1991, 42(2): 177-187.
Tamura M. Ranunculaceae. In: The families and genera of vascular plants. Eds K. Kubitzki, J.G. Rohwer, V. Bittrich. Berlin; Heidelberg; New York: Springer, 1993, vol. 2: Flowering Plants. Dicotyledons. Magnoliid, Hamamelid and Caryophyllid Families, pp. 563-583. https://doi.org/10.1007/978-3-662-02899-5 67

Tamura M. Phylogeny and classification of the Ranunculaceae. Plant Systematics and Evolution (Supplement), 1995, 9: 201-206. Available at: https://link.springer.com/ chapter/10.1007/978-3-7091-6612-3 20

Turland N.J., Wiersema J.H., Barrie F.R., Greuter W., Hawksworth D.L., Herendeen P.S., Knapp S., Kusber W.-H., Li D.-Z., Marhold K., May T.W., McNeill J., Monro A.M., Prado J., Price M.J., Smith G.F. International Code of Nomenclature for algae, fungi, and plants (Shenzhen Code) adopted by the Nineteenth International Botanical Congress, Shenzhen, China, July 2017. Regnum Vegetabile, 2018, 159: i-xxxviii + 1-254. https://doi.org/10.12705/Code.2018

Ulbrich E. Über die systematische Gliederung und geographische Verbreitung der Gattung Anemone L. [Part 1]. Botanische Jahrbücher für Systematik, Pflanzengeschichte und Pflanzengeographie, 1905, 37(2): $172-256$.

Ulbrich E. Über die systematische Gliederung und geographische Verbreitung der Gattung Anemone L. [Part 2]. Botanische Jahrbücher für Systematik, Pflanzengeschichte und Pflanzengeographie, 1906, 37(3): 257-334.

Wang W., Lu A.M., Ren Y., Endress M.E., Chen Z.D. Phylogeny and classification of Ranunculales: evidence from four molecular loci and morphological data. Perspectives in Plant Ecology, Evolution and Systematics, 2009, 11: 81-110. https://doi.org/10.5167/uzh-19189

Ziman S.N., Keener C.S., Kadota Y., Bulakh E.V., Tsarenko O.N. A revision of Anemone L. (Ranunculaceae) from the Southern Hemisphere. Journal of Japanese Botany, 2006, 81: 193-224. Available at: http://www.jjbotany. com/pdf/JJB_081_193_224.pdf

Ziman S.N., Bulakh E.V., Kadota Y., Keener C.S. Modern view on the taxonomy of the genus Anemone L. sensu stricto (Ranunculaceae). Journal of Japanese Botany, 2008, 83: 127-155.

Recommended for publication by D.V. Dubyna 
Мосякін С.Л. ${ }^{1}$, де Ланге П.Дж. ${ }^{2}$, Булах О.В. ${ }^{1}$

Внутрішньородові таксони для видів Anemonastrum та

Knowltonia з Південної Півкулі, які раніше включалися до Anemone sensu lato (Ranunculaceae). Укр. бот. журн., 2018, 75(6): 509-516.

${ }^{1}$ Інститут ботаніки ім. М.Г. Холодного НАН України вул. Терещенківська 2, Київ 01004, Україна

${ }^{2}$ Технологічний інститут УніТек, П/скр. 92025, вул. Вікторії (Захід), Окленд 1142, Нова Зеландія

На основі молекулярно-філогенетичних і частково також морфологічних та біогеографічних даних нещодавно було запропоновано визнати у значно розширеному розумінні роди Anemonastrum та Knowltonia, які раніше здебільшого включали до Anemone sensu lato (Ranunculaceae). Обидва ці роди включають представників, які є цікавими з морфологічної та біогеографічної точок зору, а загальні ареали цих родів (тобто, сума ареалів їхніх видів) демонструють явні міжконтинентальні диз'юнкції. Зокрема, Knowltonia в новому розумінні (що відповідає Anemone sect. Pulsatilloides sensu Hoot et al., 2012) включає південноафриканські та деякі американські (переважно південноамериканські) таксони, а також K. crassifolia 3 о-ва Тасманія. Рід Anemonastrum (що відповідає Anemone subg. Anemonidium sensu Hoot et al., за виключенням роду Hepatica) є переважно євразійським, але також містить декілька північноамериканських видів та південноамериканський $A$. antucense і новозеландський $A$. tenuicaule. Види, що зараз включені до Anemonastrum та Knowltonia, раніше розмішували в різних внутрішньородових таксонах роду Anemone sensu lato. Тепер ці внутрішньородові таксони мають бути дещо переглянуті та перенесені до відповідних родів. Ми пропонуємо в статті такі нові комбінації рангів секції та підсекції: Knowltonia sect. Mexicanae (Starod.) Mosyakin \& de Lange, comb. nov. (incl. K. mexicana); sect. Crassifoliae (Ulbr.) Mosyakin \& de Lange, comb. nov. (incl. K. crassifolia); sect. Rigidae (Ulbr.) Mosyakin \& de Lange, comb. nov. (incl. Knowltonia hootae $\equiv$ Anemone rigida, K. hepaticifolia, K. moorei); sect. Meridium (Starod.) Mosyakin \& de Lange, comb. nov. (incl. K. helleborifolia та K. peruviana), sect. Sellowiae (Hoot) Mosyakin \& de Lange, comb. nov. (incl. K. sellowii та K. assisbrasiliana); sect. Oreithales (Schltdl.) Mosyakin \& de Lange, comb. nov. (incl. K. integrifolia); sect. Barneoudia (Gay) Mosyakin \& de Lange, comb. nov. (incl. K. balliana, K. chilensis, K. major); sect. Pulsatilloides (DC.) Mosyakin \& de Lange, comb. nov., [sect. Pulsatilloides] subsect. Alchemillifoliae (Ulbr.) Mosyakin \& de Lange, comb. nov. (incl. $K$. caffra та $K$. fanninii), [sect. Pulsatilloides] subsect. Pinnatifoliae (Ulbr.) Mosyakin $\&$ de Lange, comb. nov. (incl. K. tenuifolia). Валідизована нова комбінація у ранзі виду, Knowltonia caffra (Eckl. \& Zeyh.) Christenh. \& Byng ex Mosyakin \& de Lange, comb. nov. Описана нова підсекція Anemonastrum sect. Anemonidium subsect. Makariri de Lange \& Mosyakin, subsect. nov.; ця підсекція містить Anemonastrum antucense з Південної Америки та $A$. tenuicaule з Нової Зеландії.

Ключові слова: Anemone, Knowltonia, Ranunculaceae, внутрішньородова класифікація, номенклатура, Південна півкуля, систематика
Мосякин С.Л. ${ }^{1}$, де Ланге П.Дж. ${ }^{2}$, Булах Е.В. ${ }^{1}$ Внутриродовые таксоны для видов Anemonastrum и Knowltonia из Южного полушария, которые ранее включались в Anemone sensu lato (Ranunculaceae). Укр. бот. журн., 2018, 75(6): 509-516.

${ }^{1}$ Институт ботаники им. Н.Г. Холодного НАН Украины ул. Терещенковская 2, Киев, 01004, Украина

${ }^{2}$ Технологический институт УниТек, П/я. 92025, ул. Виктории (Запад), Окленд 1142, Новая Зеландия

На основе молекулярно-филогенетических и частично также морфологических и биогеографических данных недавно было предложено признать в значительно расширенном понимании роды Anemonastrum и Knowltonia, которые ранее преимущественно включали в род Anemone sensu lato (Ranunculaceae). Оба эти рода включают представителей, которые интересны с морфологической и биогеографической точек зрения, а ареалы этих родов (то есть, сумма ареалов их видов) демонстрируют явные межконтинентальные дизъюнкции. В частности, Knowltonia в новом понимании (соответствующем Anemone sect. Pulsatilloides sensu Hoot et al., 2012) включает южноафриканские и некоторые американские (преимущественно южноамериканские) таксоны, а также K. crassifolia из о-ва Тасмания. Род Anemonastrum (coответствующий Anemone subg. Anemonidium sensu Hoot et al., за исключением рода Hepatica) преимущественно евразийский, но он также включает несколько североамериканских видов, южноамериканский $A$. antucense и новозеландский A. tenuicaule. Виды, которые сейчас включены в Anemonastrum и Knowltonia, ранее размещали в различных внутриродовых таксонах рода Anemone sensu lato. Теперь эти внутриродовые таксоны должны быть несколько пересмотрены и перенесены в соответствующие роды. Мы предлагаем здесь следующие новые номенклатурные комбинации рангов секции и подсекции: Knowltonia sect. Mexicanae (Starod.) Mosyakin \& de Lange, comb. nov. (incl. K. mexicana); sect. Crassifoliae (Ulbr.) Mosyakin \& de Lange, comb. nov. (incl. K. crassifolia); sect. Rigidae (Ulbr.) Mosyakin \& de Lange, comb. nov. (incl. Knowltonia hootae $\equiv$ Anemone rigida, K. hepaticifolia, K. moorei); sect. Meridium (Starod.) Mosyakin \& de Lange, comb. nov. (incl. K. helleborifolia и K. peruviana), sect. Sellowiae (Hoot) Mosyakin \& de Lange, comb. nov. (incl. K. sellowii и K. assisbrasiliana); sect. Oreithales (Schltdl.) Mosyakin \& de Lange, comb. nov. (incl. K. integrifolia); sect. Barneoudia (Gay) Mosyakin \& de Lange, comb. nov. (incl. K. balliana, K. chilensis, K. major); sect. Pulsatilloides (DC.) Mosyakin \& de Lange, comb. nov., [sect. Pulsatilloides] subsect. Alchemillifoliae (Ulbr.) Mosyakin \& de Lange, comb. nov. (incl. K. caffra и K. fanninii), [sect. Pulsatilloides] subsect. Pinnatifoliae (Ulbr.) Mosyakin \& de Lange, comb. nov. (incl. K. tenuifolia). Действительно обнародована новая комбинация в ранге вида, Knowltonia caffra (Eckl. \& Zeyh.) Christenh. \& Byng ex Mosyakin \& de Lange, comb. nov. Описана новая подсекция Anemonastrum sect. Anemonidium subsect. Makariri de Lange \& Mosyakin, subsect. nov.; эта подсекция включает Anemonastrum antucense из Южной Америки и A. tenuicaule из Новой Зеландии.

Ключевые слова: Anemone, Knowltonia, Ranunculaceae, внутриродовая классификация, номенклатура, систематика, Южное полушарие 